\section{DIARY}

100th FDI Annual World

Dental Congress

Date: 29 August - 1 September 2012

Location: Hong Kong

www.fdicongress.org

Maximum impact dentistry

with minimal invasion

Date: 7 September 2012

Location: Leeds

Telephone: 02075634590

Email: events@bda.org

www.bda.org/seminars

Scottish Scientific Conference: contemporary management

Date: 7 September 2012

Location: Dunblane

Telephone: 02075634590

Email: events@bda.org

www.bda.org/seminars

Resolving clinical challenges

in restorative dentistry

Date: 14 September 2012

Location: Manchester

Telephone: 02075634590

Email: events@bda.org

www.bda.org/seminars

\section{PER/IADR Congress}

Date: 12-15 September 2012

Location: Helsinki, Finland

http://iadr.com/i4a/pages/index.

$\mathrm{cfm}$ ?pageid $=3955$

Optimising Outcomes

in Restorative Dentistry

Date: 20 September 2012

Venue: Symposium Hall of the College,

The Royal College of Surgeons

of Edinburgh

Email:h.anderson@rcsed.ac.uk

Telephone: 01316689239

https://ubis.rcsed.ac.uk/courses/

coursedetails.aspx?diaryld=1027

DDU-Eastman Dento-Legal

Conference

Date: 28 September 2012

Location: London

Email: edi-cpd@ucl.ac.uk

www.the-ddu.com

Infection Prevention in Dentistry:

one day conference

Date: 1 October 2012 8.45am-4pm

Venue: ACC, Liverpool

www.eventsforce.net/dentalconf2012

BDTA Dental Showcase

Date: 4-6 October 2012

Venue: ExCeL London

www.dentalshowcase.com

\section{JOHN McGIMPSEY PRIZE}

The Faculty of Dentistry at the Royal College of Surgeons in Ireland (RCSI) has awarded the inaugural John McGimpsey Prize to Ms Caoimhe McVeigh, a final year dental student at Queen's University Belfast.

The late Professor John McGimpsey, Consultant in Oral Surgery, was Director of Teaching and Learning and Department Head at Queen's University and Royal Victoria Hospital Belfast. He was also Dean of the Faculty of Dentistry, RCSI, from 1998-2001.

The Faculty of Dentistry fosters a drive for excellence by awarding prizes to outstanding students.

\section{CORRECTION}

In the last issue of the $B D J$, a news story stated that Dr Bob Khanna was made a Visiting Professor of Maxillofacial Surgery at Madrid University (BDJ 2012; 213: 8). He was in fact made a Visiting Clinical Professor of Facial Aesthetics.

\section{HONOURS, AWARDS, APPOINTMENTS}

Director General Army Medical Services

Brigadier Ewan Carmichael BDS MBE, who qualified in Glasgow in 1982 and is late of the Royal Army Dental Corps, has been appointed to be Director General Army Medical Services in the rank of major-general from September 2012.

\section{Edinburgh graduates}

Mikaella Papastylianou has received a master's degree in oral surgery and Mr Nick Malden has received a doctorate in dental surgery from the University of Edinburgh. Mr Malden also teaches on the programme.

\section{BMPA President}

David Hillam, retired Consultant in Restorative Dentistry (Periodontology), has been elected to serve for two years as President of the British Medical Pilots Association (BMPA). Mr Hillam got his private pilots licence in 1992 flying mainly four-seat Piper Cherokees and built a two-seat Europa over a period of eight years, completed in 2003. Last year he had an aerobatic lesson for his $70^{\text {th }}$ birthday.

\section{Distinguished scientist}

Professor Helen Worthington has received the 2012 International Association for Dental Research (IADR) H. Trendley Dean Memorial Distinguished Scientist Award. Professor Worthington is Professor of Evidence-Based Care in the School of Dentistry at the University of Manchester and is an international leader in evidence-based dentistry with over 40 years of experience.

\title{
ESSENTIAL DENTAL FACILITIES FOR ROYAL MARINES
}

An official ceremony has been held at 42 Commando

Royal Marines in Bickleigh, Plymouth, to mark the completion of a new centre that will provide modern medical and dental care facilities and essential services for the treatment and rehabilitation of injured marines in a single, contemporary building. Commander Carol Betteridge and Royal Marine William Cassidy Little unveiled a commemorative plaque.

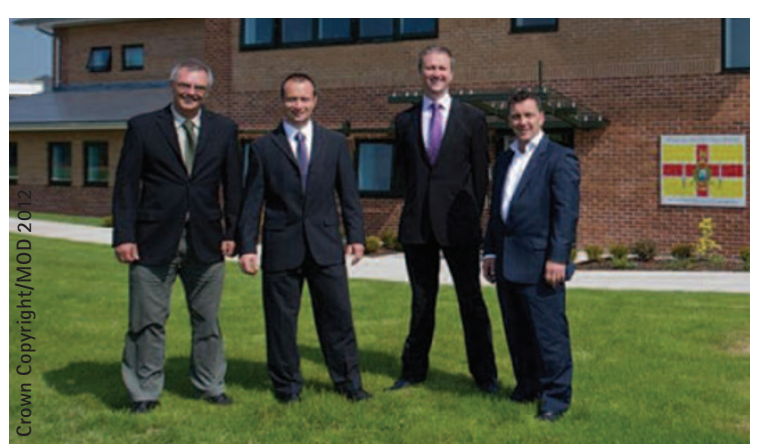

From left: Graham Martin, DIO Project Manager; Dave Delicate, the Navy Command Infrastructure Capability Manager; Paul Nix, Lend Lease and Debut Core Works Director; Matthew Lee, Debut Core Works Project Manager
The new building provides enhanced clinical care for patients with a full range of treatment and preventive medicine, including a physiotherapy suite. It was delivered by the Defence Infrastructure Organisation (DIO) working with regional industry partner Debut Services (South West) Limited.

'The new medical and dental centre is an excellent example of what can be achieved through teamwork and appropriate stakeholder engagement,' said Dave Delicate, the Navy Command Infrastructure Capability Manager. 'This project has benefitted from a number of lessons learnt from previous new build medical and dental centres, and will provide the Royal Marines at 42 Commando in Bickleigh Barracks with a facility that they so richly deserve.' 